This is an accepted manuscript of a book chapter published by Routledge in Sullivan, Jonathan and Lee, Chun-Yi (eds) A New Era in Democratic Taiwan Trajectories and Turning Points in Politics and Cross-Strait Relation, 2018. Published version available from: https://www.routledge.com/A-New-Era-in-Democratic-Taiwan-Trajectoriesand-Turning-Points-in-Politics/Sullivan-Lee/p/book/9781138062429

Accepted version downloaded from SOAS Research Online: http://eprints.soas.ac.uk/26193/

\title{
Taiwan's Political Parties in the aftermath of the 2016 Elections
}

\section{Dafydd Fell (SOAS Department of Politics and International Studies)}

Political parties are an essential feature in modern democracies. They play a central role in political recruitment, policy direction for government, simplifying politics, and linking state with society. One way we can assess the health of a democracy is whether it has strong parties and a relatively stable party system. On the surface Taiwan has one of the most stable party systems among Asian democracies. In Taiwan's first multi-party election held in 1986, the Kuomintang (KMT) and Democratic Progressive Party (DPP) won the vast majority of contested seats. Over the last three decades, though other parties have entered the party system, they have almost never threatened the domination of the DPP and KMT. Three decades later in the most recent national election in January 2016, the same two parties dominated the parliamentary and presidential elections. Despite the continuity in actors, as a long term observer of Taiwan's party scene, I argue that since 2014 we have witnessed monumental changes in the party system.

This chapter attempts to paint a picture of Taiwan's changing party scene in the build up to and aftermath of the 2016 elections. An understanding of the party scene requires us to examine both the development of key individual parties and the overall party system. Alan Ware defines the party system as 'patterns of competition and co-operation between the different parties in that system.' ${ }^{1}$ Thus studies of the party system consider fragmentation, ideological positioning, the openness of the system to new entrants and the relationship between the relevant political parties. Party system fragmentation can have important implications for the way a democracy operates. A democratic but one party dominant system can operate in a similar way to an authoritarian state, as there are no genuine checks on the ruling party. However, where a party system is too fragmented it may lead to political instability and frequent government coalition breakdowns. Ideological positioning has similar ramifications. Where parties are too convergent, voters may complain that there is little to choose from between the main competitors. However, when parties are concentrated at the poles, there is the possibility that more extremist anti-system parties may undermine the democratic system.

Party and party system change are huge topics so my analysis focuses on a more limited number of aspects to the changing party scene. In the first section I briefly discuss changes in party strength and fragmentation by looking at both election results but also campaign spending data. The second section considers change in terms of parties' treatment of political issues during the campaign. This allows us to get a sense of whether the main parties are converging or becoming more polarised. I have done this by examining how the parties' address the most salient issues in their election advertising. The three broad issue

\footnotetext{
${ }^{1}$ Alan Ware, Political Parties and Party Systems (Oxford: Oxford University Press, 1996), 7.
} 
This is an accepted manuscript of a book chapter published by Routledge in Sullivan, Jonathan and Lee, Chun-Yi (eds) A New Era in Democratic Taiwan Trajectories and Turning Points in Politics and Cross-Strait Relation, 2018. Published version available from: https://www.routledge.com/A-New-Era-in-Democratic-Taiwan-Trajectoriesand-Turning-Points-in-Politics/Sullivan-Lee/p/book/9781138062429

Accepted version downloaded from SOAS Research Online: http://eprints.soas.ac.uk/26193/

areas that have been especially salient in recent years are (1) national identity, (2) Taiwan's economic relationship with China, and (3) social movements. Any study of Taiwanese party positioning needs to take into account questions of national identification, as it is widely regarded as having been the central political cleavage in Taiwan since democratization. ${ }^{2}$ The second two issue areas have grown in salience over the last decade, as Taiwan has become increasingly economically integrated with China there have been concerns that this process could undermine Taiwan's freedom and democracy. Such concerns led to the emergence of the Sunflower Movement against the Cross-Strait Service Trade Agreement (CSSTA) in the spring of 2014. Although the China factor does feature in many of Taiwan's social movements, the growing protest scene is much more diverse, thus I have chosen to examine party treatment of this topic separately. In each case the issues are framed as leftright spectrums and advertising analysis is used as evidence to plot the parties' positions on these spectrums.

\section{Party System Fragmentation}

Examinations of party system fragmentation particularly focus on the number of relevant parties and their relative size and strength. The first place to get a sense of the degree of change on this dimension of the party system is elections results. During Taiwan's democratic transition period it seemed to be holding at least one major election each year. In recent years there has been a consolidation of the election calendar, so that every four years all national elections are held on the same day and there has been a similar concentration of local elections. Thus during the second Ma Ying-jeou (馬英九) term all the local elections were held on November 29, 2014, just over six months after the end of the Sunflower Occupation. Local elections can often serve as warnings for subsequent national elections. Just over two and a half years before KMT lost power in 2000, the DPP's vote and seat share exceeded those of the KMT's for the first time in 1997. The KMT's decisive election victories in 2008 were preceded by similar landslide local victories in 2005 . The local elections in November 2014 also saw landslide victories for the DPP, as the party enjoyed its best ever local executive results. That year the DPP won 13 out of the 22 local executive seats, with the KMT winning just 6 . Thus the KMT had suffered its worst ever local elections results. These elections meant that at the local level the DPP was the dominant party for the first time and served as an ominous warning for the ruling KMT.

\section{Tables 1-3 here}

The DPP gained similar domination of the party system at the national level just over a year later. Tables 1-3 give a picture of continuity and change since democratization began in the mid 1980s. Table 1 shows the party vote shares in parliamentary elections, Table 2 shows seat shares in parliamentary elections and Table 3 shows presidential vote share. Taken

\footnotetext{
2 John Hsieh, "Continuity and Change in Taiwan's Electoral Politics," in John Hsieh and David Newman (eds), How Asia Votes, (New York: Chatham House Publishing), 32-49, 38.
} 
This is an accepted manuscript of a book chapter published by Routledge in Sullivan, Jonathan and Lee, Chun-Yi (eds) A New Era in Democratic Taiwan Trajectories and Turning Points in Politics and Cross-Strait Relation, 2018. Published version available from: https://www.routledge.com/A-New-Era-in-Democratic-Taiwan-Trajectories-andTurning-Points-in-Politics/Sullivan-Lee/p/book/9781138062429

Accepted version downloaded from SOAS Research Online: http://eprints.soas.ac.uk/26193/

together we can see that although the number of relevant parties remained at four, there has been radical change in the makeup of the party system in 2016. Firstly, the elections left the DPP with unprecedented majorities and thus control of both local and national government. In the presidential election Tsai enjoyed the biggest margin of victory since Lee Teng-hui's (李登輝) in 1996. In the parliamentary election the DPP had its best ever performance both in terms of vote and especially seat share. For the first time ever, the DPP has a majority in parliament. In contrast, this was the KMT's worst ever national election result. It is true that Eric Chu's (朱立倫) vote share was higher than Lien Chan's (連戰) in 2000 and the KMT's seat share in 2016 (30\%) is almost the same as its earlier low point in 2001's legislative election. However, in 2000 the combined score of the official and rebel KMT presidential candidates was 60\% and in both 2001 and 2004 the KMT together with its ally, the People First Party (PFP), retained a parliamentary majority. We see a similar picture of change in the party system in party identification trends. Almost as soon as the KMT won re-election in 2012 its support rate began to decline drastically, while the DPP's support rate grew gradually. By the time of the 2014 election the DPP had a clear lead over the KMT for the first time since the early 2000s. In the most recent survey the DPP enjoyed its highest ever party identification figure of $31 \%$ and its widest ever lead over the KMT. ${ }^{3}$ Thus the party identification trends mirror those seen in the 2014 and 2016 election results of the DPP as the dominant party in a two party system.

Another way we can get a sense of the relative strength of the main parties is in the resources employed during the election campaign. The KMT has the reputation as being one of the richest parties in the world and this has allowed it to vastly outspend its rivals in the majority of election campaigns. ${ }^{4}$ Chen and Fell's study showed that in 2012 the KMT purchased significantly more election advertisements compared to the DPP. ${ }^{5}$ Table 4 summarises campaign advertising spending for the presidential and party headquarters in the 2012 and 2016 campaigns. The first change that catches the eye is the fact that campaign spending by both the major parties drastically declined in 2016 compared to 2012 . It should be noted here that these figures only include spending on TV, newspaper, magazine and radio advertising. Thus one possibility is that parties have shifted their spending to the internet and social media. Nevertheless, we can see how the gap between the parties has narrowed significantly. Although the KMT's total spending on advertising

\footnotetext{
${ }^{3}$ It is true the DPP had similar leads in party identification over the KMT in 2001 and 2002. However, if the KMT and PFP support levels were combined they still exceeded those of the DPP.

4 For more on KMT party assets see Xu, Dianqing, (1997) “The KMT Party's Enterprises in Taiwan," Modern Asian Studies, 31 (2), 399-413.
}

\footnotetext{
${ }^{5}$ Fell, Dafydd and Chen, I-hsin Charles (2014) 'Lessons of Defeat and Success: Taiwan's 2012 Elections in Comparative Perspective.' Journal of Current Chinese Affairs, 43 (3).
} 
This is an accepted manuscript of a book chapter published by Routledge in Sullivan, Jonathan and Lee, Chun-Yi (eds) A New Era in Democratic Taiwan Trajectories and Turning Points in Politics and Cross-Strait Relation, 2018. Published version available from: https://www.routledge.com/A-New-Era-in-Democratic-Taiwan-Trajectories-andTurning-Points-in-Politics/Sullivan-Lee/p/book/9781138062429

Accepted version downloaded from SOAS Research Online: http://eprints.soas.ac.uk/26193/

exceeded the DPP's in the campaign, at least in terms of presidential advertising spending, the DPP spent slightly more.

\section{Table 4 here}

Despite high levels of distrust of Taiwan's mainstream parties and much talk of the arrival of a third force in Taiwanese politics, Tables 1-3 and Figure 1 suggest limited change in party system openness. On the back of James Soong's improved 2016 presidential campaign, the KMT splinter party, the PFP, was able to increase its vote share and match its 2012 achievement of wining three seats. Given that the PFP caucus did not play a particularly prominent role in the second Ma term, it is uncertain whether they will be more visible in the first Tsai term. In 2012 the Taiwan Solidarity Union (TSU) surprised many observers by winning almost 9 percent of the party list vote and three parliamentary seats. Four years later the TSU vote collapsed, gaining only 2.5 percent and it failed to win any seats.

Nevertheless, there are a number of reasons that the campaigns of Taiwan's smaller parties since 2014 are worthy of attention for our understanding of the new party system. Firstly, the TSU was replaced by the newly formed the New Power Party (NPP), winning five seats. The NPP is likely to have a greater impact on the new party system than the TSU (or the PFP). A sign of its potential is that the NPP was able to win three single member districts. Naturally the fact that the DPP did not nominate in these districts played a role, but these were relatively safe KMT seats. A key factor in the NPP's breakthrough is that it has much better known candidates than the other small parties. For example, the Sunflower movement leader Huang Kuo-chang (黃國昌) and rock musician Freddy Lim were able to defeat veteran incumbent KMT legislators. Well known politicians also tend to bring greater levels of media attention. Moreover, the NPP's leaders and newly elected politicians are not traditional politicians. In other words, unlike most other small splinter party politicians, the NPP's legislators are not defectors from mainstream parties. The fact that the NPP was able to make a breakthrough despite very low levels of advertising spending reveals the party's potential and suggests it has relied heavily on new technology to reach voters. One challenge about the NPP is how to best categorise the party. Should we view it as a Pan Green party, like the TSU? Or should it be seen as an alternative party. This is a topic I will return to in the section on ideological positioning later in the chapter.

\section{Table 5 here}

A second noteworthy element to the campaign was that while support for smaller parties was higher than the previous two elections under the new system, competition was very intense for those votes. In fact in 2016 there was a record 18 parties contesting the party list. The vote shares of the party list section is shown in Table 5. Moreover, a larger number than ever of these actually ran serious campaigns. We can see this for instance in the advertising spending figures shown on Table 4. For instance, the Chinese Unification Promotion Party (CUPP) and Min Kuo Tang (MKT) were among the highest spenders on traditional advertising. 
This is an accepted manuscript of a book chapter published by Routledge in Sullivan, Jonathan and Lee, Chun-Yi (eds) A New Era in Democratic Taiwan Trajectories and Turning Points in Politics and Cross-Strait Relation, 2018. Published version available from: https://www.routledge.com/A-New-Era-in-Democratic-Taiwan-Trajectoriesand-Turning-Points-in-Politics/Sullivan-Lee/p/book/9781138062429

Accepted version downloaded from SOAS Research Online: http://eprints.soas.ac.uk/26193/

While in earlier campaigns many of the smaller parties on the party list were really just making up the numbers, in 2016 a number of these parties made serious attempts to break into the party system and break the DPP/KMT domination. For example, the MKT made a massive membership recruitment drive, claiming within months to be the third largest party and aiming to become the largest. ${ }^{6}$ Another example was the attempt by the Green Party (GPT) to create an alliance with trade union groups and to establish active local party branches.

The third noteworthy element of the smaller parties has been how their political projects have become more diverse. For the first time Taiwan had an openly pro PRC political party in the CUPP. The GPT/SDP campaign represents the most serious left wing campaign since the late 1980s. Another interesting case was the Faith and Hope Alliance (FHA) which was widely viewed as a single issue grouping motivated by the desire to block legislation on same sex marriage and adoption. Naturally there were also attempts to establish new purifier parties on both sides of the political spectrum, for example there were two new pro independence parties. However, the fact that despite the growing support for non mainstream parties and their improved campaigns, the fact that only the NPP and PFP among the smaller parties was able to win seats reveals the challenges faced by challengers to enter the party system.

\section{Ideological Movement}

In this section I examine how the main parties have dealt with three key issue areas that have been salient since 2014. As mentioned earlier, the three broad issue areas I have selected to focus on are debates over national identification, Taiwan's economic relations with China, and debates over social movements. In each case I have tried to place the parties on issue spectrums. Thus I attempt to show whether the parties are taking centrist or polarised positions, and at least where parties had joined earlier elections, I also attempt to paint a rough picture of whether parties are shifting towards the centre or towards the poles.

\section{Competing National identities}

The main issue spectrum used to examine party positions in Taiwan revolves around the national identification debates. One of the most common methods has been to use surveys to ask voters to locate themselves and the main parties on a spectrum in which one end calls for rapid unification with China and the other end for immediate declaration of

\footnotetext{
${ }^{6}$ Fang Bing-chao, "Aiming to exceed the second largest party, the MKT will nominate a presidential candidate," Storm Media, June 23, 2015, http://www.storm.mg/article/54329
} 
This is an accepted manuscript of a book chapter published by Routledge in Sullivan, Jonathan and Lee, Chun-Yi (eds) A New Era in Democratic Taiwan Trajectories and Turning Points in Politics and Cross-Strait Relation, 2018. Published version available from: https://www.routledge.com/A-New-Era-in-Democratic-Taiwan-Trajectoriesand-Turning-Points-in-Politics/Sullivan-Lee/p/book/9781138062429

Accepted version downloaded from SOAS Research Online: http://eprints.soas.ac.uk/26193/

independence. ${ }^{7}$ An alternative method that I have used over the last decade has been to use parties' advertising material as the basis for plotting their positions on a range of issues, including national identification. There are two main survey question that address national identity in Taiwan. These are (1) whether respondents prefer unification or independence, and (2) whether respondents see themselves as Taiwanese, Chinese or both. I have tried to use the way parties' political advertising address both the political relationship with China question and the more symbolic identification appeals to plot their positions. The spectrum I use consists of five broad types. At the far right is what I call Greater Chinese or PRC Chinese nationalism and includes positive references to unification, including the PRC's proposal for One Country Two Systems. In addition this also includes symbolic appeals associated with unification such as the PRC flag or Chiang Kai-shek. At the centre right is ROC style Chinese nationalism. Here though we will see opposition to Taiwan independence, there will not be positive references for unification. Instead the focus is on protecting the ROC and use of ROC symbols. In the middle of the spectrum are references to maintaining the status quo of neither full independence nor unification, as well as appeals to dual Chinese and Taiwanese identity. Next we come to the centre left position I have termed civic Taiwanese nationalism. This will feature opposition to unification but not support for an outright declaration of independence. Instead it features softer appeals such as self determination or the idea that there is no need to declare independence as Taiwan is already independent. The symbolic appeals tend also to be more inclusive of all Taiwan's ethnic groups. Lastly, at the far left is what I term ethnic Taiwanese nationalism. Here we see calls for declaring a Republic of Taiwan but also exclusive ethnic appeals, such as antiMainlander messages.

Although the national identity debates were perhaps not as intense as some of those seen in the 1990s, the main parties appealed to voters with a diverse range of appeals from extreme Chinese nationalism at one end of the spectrum to calls for de jure independence at the other. The appearance for the first time in a national election by the CUPP was significant for a number of reasons. Firstly, as we saw earlier it was one of the heaviest spenders on advertising in the election, thus in contrast to earlier pro unification new parties, it was running a serious campaign. Equally importantly though was its positioning at the far right on the unification versus independence spectrum. The CUPP was the first serious party to openly advocate unification under the PRC's preferred formula of one country two systems (OCTS). ${ }^{8}$ Therefore the election allowed for a test of the suitability of the PRC's nationalist message for Taiwan's population. The CUPP's first TV ad released on December 26 was narrated by its party leader Chang An-lo (張安樂). Chang argued that now

\footnotetext{
${ }^{7}$ For instance John Hsieh, "Continuity and Change in Taiwan's Electoral Politics," in John Hsieh and David Newman (eds), How Asia Votes, (New York: Chatham House Publishing), 32-49, 38-40.

${ }^{8}$ The only other case I have come across was when NP legislator Elmer Feng also used One Country Two Systems in his 2001 bus advertisements. At the time the NP officially talked of One Country Three Systems.
} 
was the right time to negotiate Taiwan's unification under OCTS and warned that this was much better than waiting to be unified in war. A number of the CUPP's newspaper ads offered further detail on its thinking behind its unification proposals. One such ad noted that, 'Many friends that care about the CUPP have told us for the sake of votes do not emphasize the word unification; otherwise you will be labelled red. However, the red proposal for peaceful unification, one country two systems, is the best guarantee for the wellbeing of Taiwan's people. ${ }^{9}$ The CUPP's proximity to the PRC was seen in the same ad where it states, “We are the real orthodox red flag" (我們是真正的正紅旗). Therefore we can safely place the CUPP at the far right of our national identity spectrum.

Previously, the NP had dominated the far right of the national identity spectrum, but the arrival of the CUPP meant it had a competitor. Protecting the Republic of China (ROC) and opposition to Taiwan independence have been constant themes for the NP. However, the party became increasingly extreme and narrowly focused from 1998, contributing to its subsequent electoral decline. ${ }^{10}$ In recent years the party has continued this shift towards the extreme end of the national identity spectrum. The party's appeal is clear from its website which describes itself as 'the political party for Chinese' and lists unification as one of its four core appeals. ${ }^{11}$ In the NP's advertising it did not mention unification in 2016. Its only reference to future political relations with China was a call for signing a peace agreement (with China). ${ }^{12}$ Naturally the parties' highlighting of its party leader Yu Mu-ming (郁慕明), PR candidates Chiu Yi (邱毅) and Wang Bing-zhong (王炳忠), all who are well known for their pro China positions, did reinforce the party's image. As in earlier elections, the ROC flag featured prominently and its first TV ad did use its old slogan 'Protect the ROC. ${ }^{13}$ However, while the CUPP called itself the true red party, the NP emphasized itself as being the "true Blue party," thus it should be placed slightly to the left of the CUPP.

One of the challenges for plotting the KMT's position on national identity in the 2016 election was the fact that it had changed presidential candidates so late in the campaign and one of the justifications for replacing Hung was that her identity positions were out of step from mainstream Taiwanese public opinion. Chu tried to project an image as someone more moderate than Hung, and his advertising appeals on national identity overlapped heavily with those used by Ma in 2012. While Ma's core slogan was 台灣加油 (Go Taiwan),

\footnotetext{
${ }^{9}$ China Times, Dec 25, 2015, A1.

${ }^{10}$ For a discussion of the rise and decline of the NP see Fell, Dafydd (2006) 'The Rise and Decline of the New Party: Ideology, Resources and the Political Opportunity Structure.' East Asia: An International Quarterly, 23 (1). pp. 47-67.

${ }^{11}$ http://www.np.org.tw/

${ }^{12}$ December 17, China Times, A5.

${ }^{13}$ Broadcast December 30, 2015.
} 
This is an accepted manuscript of a book chapter published by Routledge in Sullivan, Jonathan and Lee, Chun-Yi (eds) A New Era in Democratic Taiwan Trajectories and Turning Points in Politics and Cross-Strait Relation, 2018. Published version available from: https://www.routledge.com/A-New-Era-in-Democratic-Taiwan-Trajectories-andTurning-Points-in-Politics/Sullivan-Lee/p/book/9781138062429

Accepted version downloaded from SOAS Research Online: http://eprints.soas.ac.uk/26193/

Chu selected “One Taiwan” and 台灣就是力量 (Taiwan is the force). In a number of ads Chu tried to elaborate on his concept of One Taiwan. For instance, in his November 25 TV ad he distinguishes between two Taiwans, "one is where we argue with each other, one is a Taiwan where we embrace each other." He goes on to accuse the DPP of being divisive, noting how 'Although some people can divide Taiwan into four or eight, but I would rather work hard to make the two opposed Taiwans return to that warm and mutually trusting Taiwan.' This is something Chu returned to in his December 27 TV ad. This ad again stressed the inclusive appeal by using multiple languages and multiple ethnicities. The first speaker tells us that 'There used to be a Taiwan where you would not be suspected and rejected because you have different points of views.' Since we are told that was when Taiwan created a miracle, we can surmise that this golden era refers to the Chiang Ching-kuo soft authoritarian years that are most associated with Taiwan's economic miracle. Then we are told that 'At that time we all believed we were part of each other.' (那個時候我們都相信彼 此是彼此的一部分). Chu ends the ad by saying, 'From today let us reject being divisive and oppositional. Let us rediscover that Taiwan that belongs to us.' (從今天起, 讓我們拒絕分割 對立，找回屬於我們的台灣). This ad's message is thus very similar to that used by Ma in his often recycled Happy Gathering Song (歡聚歌) ads, that stress how all Taiwanese are one happy family, but in doing so these ads also insinuate that the DPP is inciting ethnic divisions. The difference between $\mathrm{Ma}$ and Chu though was that while for Ma this ethnic harmony was something he had helped to create, but for Chu that utopia lay in Taiwan's past. It is rather ironic that most of those talking of that golden past in Chu's ad could not have been alive at the time of Chiang Ching-kuo's presidency.

In addition to this inclusive Taiwan message, Chu did need to appeal to those traditional supporters with ROC identities, including those that had originally supported Hung's aborted presidential campaign. The ROC flag became more prominent in KMT ads in the final two weeks of the campaign. Its prime pre-election weekend rally was titled "National Flag Party" (國旗 Party) and participants were encouraged to wear anything with an ROC flag on it. ${ }^{14}$ Again this was something seen in Ma's 2012 campaign, not only in Ma's ads but also his micro-film National Flag Girl (國旗的女孩). ${ }^{15}$ Both were attempting to make ROC nationalism young and cool. To a certain extent party unity meant that Chu needed to reach out to dark blue supporters, or risk them defecting to the NP or even CUPP. We saw this in the advertisements featuring Hung in an exhibition room about the KMT and ROC's history. ${ }^{16}$ The camera shows images of Chiang Ching-kuo, Sun Yat Sen, the KMT and ROC flags, and the ROC Constitution. She explains why she has remained in the KMT, because 'Some people want to change our passports, to put an end to our country,' (有些人想換掉

\footnotetext{
14 Jan 7, China Times, A7.

${ }^{15}$ https://www.youtube.com/watch?v=OatkmnEiBzO

${ }^{16}$ Broadcast January 1, 2016.
} 
This is an accepted manuscript of a book chapter published by Routledge in Sullivan, Jonathan and Lee, Chun-Yi (eds) A New Era in Democratic Taiwan Trajectories and Turning Points in Politics and Cross-Strait Relation, 2018. Published version available from: https://www.routledge.com/A-New-Era-in-Democratic-Taiwan-Trajectoriesand-Turning-Points-in-Politics/Sullivan-Lee/p/book/9781138062429

Accepted version downloaded from SOAS Research Online: http://eprints.soas.ac.uk/26193/

你我的護照, 像終結這個國家). She ends the ad saying, 'I am Hung Hsiu-chu, I love my country, the ROC.' (我是洪秀柱我愛我的國家，中華民國)Then hear her rally location call 'Let us come together to support Eric Chu.'( 讓我們一起支持朱立倫).

I have located the two other KMT splinter parties, the PFP and MKT, closer to the centre than the KMT. Although in the past the PFP had been associated with the Dark Blue side of Taiwanese politics for much of the Chen Shui-bian (陳水扁) (2000-2008) era, it had become much more Taiwan focused since the 2012 campaign. It proposes setting aside the unification versus independence dispute and insists that any future changes to Taiwan's status need the approval of the Taiwanese people. ${ }^{17}$ Its 2016 ads did not feature the ROC flag or references to protecting the ROC. The political platform adopted by the newly established MKT appeared quite similar to the PFP. Its selection of the ROC emblem (with a yellow background) as its party badge is further evidence it should be regarded as a Pan Blue party. At the party's opening ceremony the party flag and ROC flag were placed to the left and right of a portrait of Sun Yat Sen. The similarly moderate positioning compared with the PFP on the national identity spectrum can be seen in its first few lines of its party song, 'Republic of China MKT, Love the People, Love Taiwan. ${ }^{\text {,18 }}$

DPP was especially cautious in this election in its references to national identity. For some of Tsai's supporters her emphasis on maintaining the status quo of neither independence nor unification was seen as a betrayal of the DPP's values. Her 2016 core election slogan was the rather vague "Light Up Taiwan” (點亮台灣) and like Ma in 2012 a number of ads featured the slogan Go Taiwan (台灣加油). Unlike many earlier DPP campaigns there were no antiunification appeals or even attacks of the KMT's China policy. Instead the Tsai attempted to project an inclusive identity message to counteract the common KMT accusation that the DPP was stirring up ethnic tensions and was biased against non Hokklo ethnic groups. For example, one line in her December 29, 2015 and January 6, 2016 TV ads notes that 'maybe we do not understand each other enough; maybe we are not tolerant enough of each other.' Her inclusive message was also clear in the multiple language use in her advertising. In Tsai's first TV ad on September 17, 2015 she mixed Taiwanese, Hakka and Mandarin, while in her December 15, 2015 one minute ad she narrates almost all in Hakka. She was also supported in a number of campaign events by the award winning Hakka language singer Lin Sheng-hsiang (林生祥). We also see this inclusive identity message in the way an ultimate symbol of Chinese nationalism, a statue of Chiang Kai-shek, is shown followed immediately by a clip of a Taiwan independence flag, while the narrator notes, 'What has passed has passed.' (所有過去的已經過去了). ${ }^{19}$ Overall then we can take the DPP as de-

\footnotetext{
${ }^{17}$ http://www.pfp.org.tw/Party Show.asp?id=3

${ }^{18}$ https://www.mkt.org.tw/Home

${ }^{19}$ Broadcast December 29, 2015.
} 
This is an accepted manuscript of a book chapter published by Routledge in Sullivan, Jonathan and Lee, Chun-Yi (eds) A New Era in Democratic Taiwan Trajectories and Turning Points in Politics and Cross-Strait Relation, 2018. Published version available from: https://www.routledge.com/A-New-Era-in-Democratic-Taiwan-Trajectoriesand-Turning-Points-in-Politics/Sullivan-Lee/p/book/9781138062429

Accepted version downloaded from SOAS Research Online: http://eprints.soas.ac.uk/26193/

emphasising national identity but also moving slightly further towards the centre compared to 2012.

In recent elections the TSU had been able to dominate the issue space to the left of the DPP on the unification versus independence debates. However, as was the case at the far right of the spectrum, the far left also became more competitive. The NPP adopted a position to the left of the DPP but quite similar to the DPP of the 2008 election. Among the NPP's three basic advocacies, the first is, "The NPP advocates normalizing the country's status." 20 Similarly in the party's party list TV we see it protesting against the Ma-Xi meeting in Singapore. However, though the NPP was competing for voters supporting independence with the TSU, this was just one of a variety of its social movement appeals.

In contrast the TSU had a much greater focus on opposition to China. For example one of its TV ads showed a university student throwing the book Formosa Betrayed at President Ma and as he was being held to the ground by security agents shouting 'Taiwan and China one country on each side.' A number of its TV ads used the case of Hong Kong to discredit the PRC's (and CUPP) OCTS unification formula. The ad featured images of violent police handling of Hong Kong's Umbrella movement and the narrator (speaking in Cantonese or Mandarin with a Cantonese accent) telling viewers, 'Taiwan's friends, you still have the chance, you must stand firm, don't let today's Hong Kong become tomorrow's Taiwan.' One way that its anti China message was visualised was in the form of weighing scales. The viewer is told how the KMT and PFP are so pro China, the scales are tipping in China's direction. The narrator explains how the DPP will be constrained because it will need to look after different views (once in power) and so Taiwan needs the TSU to keep the scales balanced. Almost all the TSU's ads featured TSU protests against either political or economic ties with China. Unsurprisingly the TSU brands itself as 'Number One Anti China Brand.' (抗 中第一品牌). However, unlike earlier elections, the TSU did not talk of declaring independence, thus should not be placed at far left as another new party, the Free Taiwan Party led by Tsai Ting-kuei (蔡丁貴) has attempted to claim that spot. Its TV ad stated 'Taiwan is Taiwan not China, it is not Chinese Taipei', 台灣就是台灣不是中國，不是中華台 北). Among its demands it called for Scrapping the ROC Constitution and independence by 2020. Thus the Free Taiwan Party's position is quite similar to the DPP's at its most extreme in 1991.

\section{Economic ties with China}

Despite Taiwan's growing economic integration with China, it was not until well into the DPP era that it became a salient electoral issue. For example, from the mid 1990s through until early into the DPP era, the only party that really tried to win votes on this issue was the NP.

\footnotetext{
${ }^{20}$ https://www.newpowerparty.tw/proposal
} 
This is an accepted manuscript of a book chapter published by Routledge in Sullivan, Jonathan and Lee, Chun-Yi (eds) A New Era in Democratic Taiwan Trajectories and Turning Points in Politics and Cross-Strait Relation, 2018. Published version available from: https://www.routledge.com/A-New-Era-in-Democratic-Taiwan-Trajectoriesand-Turning-Points-in-Politics/Sullivan-Lee/p/book/9781138062429

Accepted version downloaded from SOAS Research Online: http://eprints.soas.ac.uk/26193/

It forcefully argued for trade and investment liberalization with China at the time. ${ }^{21}$ Towards the end of the DPP era the picture changed as TSU began warning of the risks of integration, while the KMT adopted the NP's cross-Strait blueprint with the clear message that economic integration with China offered a solution to Taiwan's economic woes. In the 2008 campaign the DPP joined the TSU in warning of the dangers of the KMT's plans on economic integration. It warned how the KMT planned what it called the One China Common Market (一中市場) and in particular the threat of Chinese labour. The issue would remain highly salient throughout the Ma era. Once it came to power, the KMT began to implement its blueprint of integration with a series of Cross-Strait economic agreements, with ECFA the most significant in the summer of $2010 .{ }^{22}$ While in 2008 the parties debated about what would or could happen if Taiwan became economically integrated with China, in 2012 the parties debated what had actually happened. Thus much of the KMT propaganda stressed the positive economic benefits of integration, particularly for Taiwanese farmers, as well as the tourist industry. ${ }^{23} \mathrm{~A}$ number of KMT ads compared these economic developments with the bleak picture under the DPP. The KMT did also attack the DPP on this issue, warning how the fruits of cross-Strait relations would be destroyed if the DPP were to come back to power. ${ }^{24}$ In contrast to earlier elections the DPP was quiet on the issue, no longer opposing ECFA or the agreements signed, instead it preferred to focus its attention on domestic issues. There was an overall consensus that in 2012 the cross-Strait economic issue was a key factor in the KMT's ability to win re-election. ${ }^{25}$

\footnotetext{
${ }^{21}$ For a discussion of the development of this topic as an electoral issue from the 1990s through to 2012 see Fell, Dafydd (2015) 'The China Impact on Taiwan's Elections: Cross-Strait Economic Integration through the Lens of Election Advertising.' In: Schubert, Gunter, (ed.), Taiwan and The 'China Impact' Challenges and Opportunities. Routledge, pp. 53-69. (Routledge Research on Taiwan)

${ }^{22}$ For a comprehensive discussion of cross-Strait integration through to 2015 see Lee Pei-shan and Chu Yunhan, "Cross-Strait Economic Integration (1992-2015), in Gunter Schubert ed, Routledge Handbook of Contemporary Taiwan (London: Routledge, 2016), 410-425.

${ }^{23}$ For detailed discussion of the 2012 ads on this issue see Fell, Dafydd (2015) 'The China Impact on Taiwan's Elections: Cross-Strait Economic Integration through the Lens of Election Advertising.' 53-69.

${ }^{24}$ KMT support advertisement China Times, December 22, 2011, A1.

${ }^{25}$ Gunter Schubert, “No Winds of Change: Taiwan's 2012 National Elections and the Post Election Fallout," Journal of Current Chinese Affairs 41 (3), 143-161.
} 
Two years later, with the advent of the Sunflower movement the atmosphere had radically changed. The pausing of cross-strait agreements and the clear shift in more cautious public opinion set the scene for the debates over this issue in the 2014 and 2016 elections. In 2014 the KMT made a concerted attempt to attack the DPP (and its social movement allies) on this issue in its advertising. For example in its November 21 ad titled 'On November 29 make a correct choice,' (11月 29 日，做一個對的選擇！), we see contrasting images of cheerful looking young business people with the chaotic scenes in the Legislative Yuan where the DPP was trying to block KMT legislation. Although cross-Strait agreements are never mentioned, viewers will immediately guess these protests must be related to cross-Strait agreements. The viewer is asked whether this is progress or locking up the country? (進步? 鎖國?). The ad ends with the plea to 'Don't let them destroy our happiness” (別讓他們拖垮 我們的幸福). ${ }^{26}$ The KMT was also willing to broaden this attack with a comparative international angle in the campaign. A much discussed case was its TV ad titled "Who was it that allowed Korea to snigger at us?" (是誰, 讓韓國在窰笑? ). ${ }^{27}$ The ad showed Korea represented by a lady in traditional Korean dress at a card table. The narrator tells us that Korea says thank you to the DPP for blocking legislation. We are told how Korea has just signed a FTA with China and how this gives Korea a major economic advantage over Taiwan and that Taiwan has 'officially become Asia's economic orphan' (正式成為亞洲的經濟孤兒). The ad ends with the questions, 'Will the DPP be able to continue its rough blocking of the next generation? Will Taiwan chose to go forward or go backwards?' As the Korean lady looks at the viewer we are told, 'Korea is watching.'

In 2016 the pattern of party emphasis on cross-Strait economic relations showed both continuity and change. Overall the issue received far less political attention than either 2008 or 2012. At opposite ends of this spectrum lay the CUPP and TSU, with both framing the economic consequences of integration through their own nationalist lenses. The CUPP argued for instance that unification under OCTS would allow Taiwan to enjoy a peace dividend, as it would save on military spending and be able to take full advantage of the mainland's resources and huge market. ${ }^{28}$ Perhaps sensing the shift in public opinion the KMT gave far less emphasis to economic ties compared to 2012 or even 2014. Often where the KMT did touch upon the issue it was in a more indirect style. For instance, in a November 252015 TV ad Chu comments, 'These last few years I often see two Taiwans. One is a Taiwan that needs to be careful and protection, one Taiwan needs to go out and take

${ }^{26}$ https://www.youtube.com/watch?v=RJRvX5D7zW4

${ }^{27}$ https://www.youtube.com/watch?v=fmjTBggNGyI

${ }^{28}$ United Daily News, Nov 27, 2016, A1. 
This is an accepted manuscript of a book chapter published by Routledge in Sullivan, Jonathan and Lee, Chun-Yi (eds) A New Era in Democratic Taiwan Trajectories and Turning Points in Politics and Cross-Strait Relation, 2018. Published version available from: https://www.routledge.com/A-New-Era-in-Democratic-Taiwan-Trajectoriesand-Turning-Points-in-Politics/Sullivan-Lee/p/book/9781138062429

Accepted version downloaded from SOAS Research Online: http://eprints.soas.ac.uk/26193/

risks.' Its newspaper ad warned that 'Only if the KMT holds on to a majority in the Legislative Yuan can cross-Strait risks be reduced. ${ }^{29}$ The ad went on to remind voters about the different formats of cross-Strait relations following the two changes of ruling parties and how we can no longer take risks with Taiwan's peace and stable development. This was thus a softer variation on the KMT's terror message that it had adopted so frequentlysince $1991 .^{30}$ I only located a single KMT TV ad the stressed the substance of the KMT's crossStrait economic integration since 2008. Moreover, this was only broadcast on January 12 , 2016, just before voting day. First we see tour buses and hear a tour bus owner stating we never realised how many people's lives could be changed by tourism, then we hear from fishery industry farmers. One notes how ECFA saved his livelihood and another says if crossStrait relations are not good then there will be no market for his (午仔魚) fish. The ad ends with a clip of mangoes trees and the head of the Yujing (known for its mangoes) Farmers Association talking about how if there is uncertainty about the future rich people will not invest (in agriculture). However, while there were dozens of such ads issued by the KMT in 2012, this was the only one in 2016. It appeared the KMT was no longer confident about campaigning on its record of cross-Strait economic achievements. Another similar absence was newspaper ads supporting the KMT and its cross-Strait policy sponsored by Taishang associations in China, something that featured very heavily in 2012.

Most other parties largely either ignored the issue or dealt with it in passing. In one PFP TV ad Soong stressed that he had the 'Cross-Strait wisdom that people could trust' (人民放心 的兩岸智慧). ${ }^{31}$ The MKT's Party Song (黨歌篇) ad included the vague line 'Cross-Strait peace needs to be developed,'(兩岸和平要發展). The DPP as in 2012 largely steered clear of the issue in its propaganda. One of the few exceptions came in its January 11, 2016 TV ad. As with many ads it was a critique on the Ma era. It first asks the viewer whether they care about key concerns such as environmental pollution, food safety and black box. The latter term, with the visual of the Legislative Yuan is a clear critique of the CSSTA procedure. The narrator then goes on to explain that what the DPP will do is to turn issues voters care about into legislation and to supervise the government on these matters.

Unsurprisingly the parties that had the reputation for being the most opposed to economic integration were the NPP and TSU, but they took a different approach in making such appeals. In the NPP's PR list TV ad we see clips from a wide range of mass social movement protests. The ad starts with the slogan “Reject the CSSTA" (退回服貿) and later clips of Sunflower protestors both inside and outside the parliament, including shots of NPP candidates. In addition though we see NPP candidate Cheng Hsiu-ling (鄭秀玲), a National

\footnotetext{
${ }^{29}$ January 8, China Times, A3.

${ }^{30}$ That terror message was DPP=Taiwan Independence=War. It was used repeatedly until 2000.

${ }^{31}$ Broadcast January 11, 2016.
} 
This is an accepted manuscript of a book chapter published by Routledge in Sullivan, Jonathan and Lee, Chun-Yi (eds) A New Era in Democratic Taiwan Trajectories and Turning Points in Politics and Cross-Strait Relation, 2018. Published version available from: https://www.routledge.com/A-New-Era-in-Democratic-Taiwan-Trajectoriesand-Turning-Points-in-Politics/Sullivan-Lee/p/book/9781138062429

Accepted version downloaded from SOAS Research Online: http://eprints.soas.ac.uk/26193/

Taiwna University) economist who has been influential in public debates on the dangers of Chinese influence on media monopoly and also over CSSTA. Thus the NPP framed its opposition to economic integration with China in terms of its place in mass social movements.

While the NPP only issued one TV ad, the TSU spent much more freely with 20 separate TV ads and numerous newspaper ads. One of the most common TSU themes was the danger of integration with China and how the TSU had consistently protested such trends. For instance its January 8, 2016 TV ad contained a long list of areas where it has tried to block integration, including its repeated attempts to allow a referendum on ECFA. The ad described the TSU as the 'boldest at opposing China' (抗中第一勇). ${ }^{32}$ Unlike the NPP ads though the TSU tended to focus on its own TSU anti China protests and only later showed brief follow up clips of the Sunflower protests, implying that the Sunflowers were a consequence of the TSU actions. For instance, in the TSU's 18 December and 26 December, 2015 ads we see clips of TSU anti CSSTA demonstrations with the party chair discussing how Chinese immigration to Taiwan is taking away Taiwanese jobs. In fact this was a message that the DPP had used quite frequently in 2008-2010. In addition to the spectre of Chinese labour, the TSU also openly made clear its opposition to including Chinese students in Taiwan into the National Health Insurance system. A similar ad on January 9, 2016 followed this migration threat with the warning of how Chinese business people were opening retail chains in Taiwan but only selling Chinese products. Another ad placed on January 9, 2016 was appealing to exactly the same people as those of the KMT's January 12 TV ad, Taiwan's farmers. The ad tells us the TSU is the one "really fighting for Taiwan's farmers"(真正為台灣 的農民) and the one 'really fighting for Taiwan's traditional industries'(真正為台灣的傳統 產業.) We see images of TSU led protests for protecting both these sectors and it is clearly implied that they are the victims of cross-Strait integration.

\section{Social movements}

Questions of protests and social movements have often featured in Taiwan's election campaigns. For example, during the 1990s the DPP stressed its role in leading Taiwan's democratic transition through protests. In contrast, the KMT painted democratization as a top down process in which it had played the leading role and its advertising tended to highlight the message that the DPP was a violent party. When the DPP was in power it was faced by KMT protests against the controversial 2004 presidential election and Red Shirts anti-corruption movement. It even attempted to poke fun at the KMT and paint it as the violent party damaging the stock market and unable to accept democracy.

32 Jan 8, 2016, Liberty Times, A5. 
This is an accepted manuscript of a book chapter published by Routledge in Sullivan, Jonathan and Lee, Chun-Yi (eds) A New Era in Democratic Taiwan Trajectories and Turning Points in Politics and Cross-Strait Relation, 2018. Published version available from: https://www.routledge.com/A-New-Era-in-Democratic-Taiwan-Trajectoriesand-Turning-Points-in-Politics/Sullivan-Lee/p/book/9781138062429

Accepted version downloaded from SOAS Research Online: http://eprints.soas.ac.uk/26193/

Given the salience of social movements in the build up and aftermath of the Sunflower Movement, it is not surprising that this was something that featured prominently in the main parties' advertising and was also reflected in their patterns of nomination.

At one end of the spectrum were the KMT's splinter and allied parties, such as the CUPP, Faith and Hope Alliance (FHA) and the NP. These parties appealed to voters with anti-social movement appeals or adopted positions opposed to those advocated by the mainstream social movement groups. This was especially clear in the case of the NP. Its January 2, 2016 TV ad opened with a cartoon scene of demonstrators holding placards showing the words "protest" (抗議). The protestors are demonized by giving them demon's eyes. They are then contrasted by social elites who will stand up to this evil force (邪惡勢力). These are then shown in the form of the NP's top ranked PR candidates Chiu Yi and Ye Yu-lan (葉每㐬蘭) who are holding Star Wars style lifesavers. The NP's December 17, 2015 newspaper ad revealed its opposition to key social movement demands. For instance, one of its candidates is listed as opposing lifting the death sentence, while another opposes 'Taiwan Independence School curriculums' (台獨課綱). ${ }^{33}$ The latter appeal placed the NP in direct opposition to the high school student led movement that had opposed controversial proposed changes to school curriculums in 2015 and had featured an occupation of the Ministry of Education. Another theme addressed by these Pan Blue parties was protection of the family, something widely understood as code for opposing LGBT rights. The NP's Su Heng (蘇恆) was listed as protecting family values. ${ }^{34}$ However, the conservative counter movement against gay marriage was most associated with the FHA. The party had only been formed in early 2015 by a number of conservative evangelical churches with the sole objective of preventing the passage of Same Sex Marriage Legislation. As we saw in Tables 1 and 4 the FHA had spent quite heavily and scored a respectable $1.69 \%$ in its first election. It is also noteworthy that the FHA had concentrated its advertising on the radio and in fact in January 2016 it was the highest spender on radio ads. The FHA's first TV ad on January 7 listed protecting the family and youth among a number of its other core policies, but the anti LGBT focus was made clearer in its January 11 TV ad that called for 'Million People Petition for a Referendum on Protecting the Family' (百萬公投連署保護家庭). The anti-social movement appeal was also apparent in the nomination of candidates by these parties. The public face of the CUPP was Chang An-lo in the campaign and he had become a household name when he led a group of his supporters in a counter protest against the Sunflower Movement in April $2014 .{ }^{35}$ The NP's nomination of Chiu Yi on its PR list was a similar anti-social movement statement. Chiu had been a KMT legislator during the Ma era and a regular on Taiwan's political talk shows since the early 2000s. He had been a frequent critic of many of the Ma era social

\footnotetext{
33 Dec 17, 2015, China Times, A5

${ }^{34}$ Dec 17, 2015, China Times, A5

${ }^{35}$ Alison Hsiao, "White Wolf leads pro-pact rally," Taipei Times, April 2, 2014,1.
} 
This is an accepted manuscript of a book chapter published by Routledge in Sullivan, Jonathan and Lee, Chun-Yi (eds) A New Era in Democratic Taiwan Trajectories and Turning Points in Politics and Cross-Strait Relation, 2018. Published version available from: https://www.routledge.com/A-New-Era-in-Democratic-Taiwan-Trajectoriesand-Turning-Points-in-Politics/Sullivan-Lee/p/book/9781138062429

Accepted version downloaded from SOAS Research Online: http://eprints.soas.ac.uk/26193/

movements. While appearing on Chinese state TV he famously accused the DPP of supporting the Sunflower movement by supplying them with bananas. After not being nominated by the KMT he stood for the NP in 2016 and his ads featured for much of the campaign on the front page of the United Daily News and China Times.

What about the ruling party, the KMT? How did it handle the social movement topic? A number of its advertisements in both 2014 and 2016 attempted to appeal to voters uncomfortable with the rise of social movements. A good example of this was the KMT's 2014 campaign ad “Let Us Quietly, Speak Loudly” ad (讓我們靜靜地，大聲說話). The ad shows a middle aged man in a classroom and a narrator offering a critique of recent developments. The narrator explains that in the current climate: 'Because you don't go on the street to protest, you are wrong. Because you quietly work hard you can $t$ snatch the microphone." (因為你不上街抗議, 所以你是錯的, 因為你只會靜靜努力, 你搶不到麥 克風). The ads ends with the man going to the voting booth with the narrator explaining 'This is Taiwan, those that do not argue have huge power. On November 29, hold your ballot paper tightly and let us quietly speak loudly.' (這裡是台灣，不吵架的人也有巨大力量， 握緊手上的選票, 11 月 29 日, 讓我們靜靜地, 大聲說話)。 ${ }^{36}$ The KMT made a similar but more direct attack on social movements in their 2016 advertisement known as I $m$ the Fifth generation ad (我是五年級生). The narrator explains how: They forbid me from using the word justice, because justice is theirs exclusively, court justice is theirs, residential justice is theirs (at this point we see protest banners behind the protagonist), economic justice is theirs, I have no justice. ${ }^{37}$ The they here can be taken as broadly referring to both the DPP and its social movement allies. We see a similar critique in the KMT $s$ January 1, 2016 TV ad. In this advertisement former presidential candidate Hung is explaining her decision to stay in the KMT and support Chu. As she is talking we see protest placards in the background, however, these were protests banners used in the Legislative Yuan by the KMT against the DPP and the Sunflower movement. Here the banners read:

Oppose Locking up the Country, Oppose wasteful internal struggle, Fight for the Economy，(反鎖過, 要開放, 反內耗, 拼經濟).

The DPP tried to handle the social movement topic in a relatively cautious manner. The party had benefitted greatly from the Sunflower effect in November 2014 and beyond. However, the party had struggled in the past with the reputation of being violent and antibusiness, and thus Tsai naturally took quite a different approach compared to the GPT and NPP who I locate at the far end of this issue spectrum. Firstly, the DPP appealed to those that supported social movements by nominating key social movement activists, especially

\footnotetext{
${ }^{36}$ https://www.youtube.com/watch?v=CLYThf2PkwM

${ }^{37}$ Although this ad was made by the Council for Industrial and Commercial Development (CDIC), it was shown on the KMT's facebook pages and was probably the most widely discussed KMT ad of the 2016 campaign.
} 
This is an accepted manuscript of a book chapter published by Routledge in Sullivan, Jonathan and Lee, Chun-Yi (eds) A New Era in Democratic Taiwan Trajectories and Turning Points in Politics and Cross-Strait Relation, 2018. Published version available from: https://www.routledge.com/A-New-Era-in-Democratic-Taiwan-Trajectoriesand-Turning-Points-in-Politics/Sullivan-Lee/p/book/9781138062429

Accepted version downloaded from SOAS Research Online: http://eprints.soas.ac.uk/26193/

on its PR list. Most noteworthy were figures such as Frida Tsai (蔡培慧), who had been leader of Taiwan Rural Front and associated with numerous land justice disputes, Yu Wan-ju (余婉如), who is a leading figure in Taiwan's fair trade movement, as well as the feminist leader Chen Man-li (陳曼麗). In fact both Yu and Chen were former leaders of Taiwan's Green Party. Moreover, the DPP stressed this nomination especially heavily in the final week of the campaign in its newspaper, TV and social media ads. Half page ads featuring these social movement linked candidates appeared on the front page of newspapers between Jan $8-10^{38}$ and a number of these candidates also featured in their own short ads that were only used on social media.

The DPP ads also included images of protest that were being used to critique the KMT. In Tsai's September 17, 2015 TV ad we see images of water cannon being used against Sunflower protestors and then police forcefully removing protesters from a protest scene. For these scenes Tsai narrates that 'While the people are looking for a government that can solve problems, the government is solving people who are looking for problems.' (人們在找 可解決問題的政府，而政府在解決找問題的人們). Tsai's TV ads also alluded to a number of key issues driving the social movement scene. For instance, in Tsai's December 29, 2015 TV ad that offers a critique of Taiwan in recent years, we see a clip of the Dapu residence that was at the centre and became a symbol of the struggle for land justice. At this point the narrator tells us that 'fairness and justice have come to a halt' (公平正義停滯了). Later in this ad we see youngsters holding the LGBT flag and a legalize gay marriage flag. The party also made gestures towards the environmental movement, for instance Chen Man-li is labelled as an environmental protection specialist ${ }^{39}$ and a number of the TV ads showed the third nuclear power station at Kenting, a clear reference to the party's anti-nuclear stance.

In addition to the DPP though there was intense competition among other non Pan Blue parties for the support of those sympathetic to social movements. This time in addition to the TSU, the GPT SDP alliance, NPP, Free Taiwan Party and Tree Party all appealed on social movement themes. Although as discussed earlier, the Free Taiwan Party's main appeal was Taiwan independence, its party leader did label himself as the 'Mastermind behind the Sunflowers' (太陽花首謀). ${ }^{40}$ The party that had the most positive representations of protests in its advertising in the election was the TSU, however, since these protests dealt almost exclusively with issues related to Taiwan's political and economic relations with China, they have been discussed in the previous two sections. It is ironic that the most openly pro protest party was the one swept away by its new rival as the DPP's allied party, the NPP, a social movement inspired party.

\footnotetext{
38 Jan 8, Liberty Times, A1

39 Jan 8, Liberty Times, A1.

40 Jan 15, Liberty Times, A5.
} 
This is an accepted manuscript of a book chapter published by Routledge in Sullivan, Jonathan and Lee, Chun-Yi (eds) A New Era in Democratic Taiwan Trajectories and Turning Points in Politics and Cross-Strait Relation, 2018. Published version available from: https://www.routledge.com/A-New-Era-in-Democratic-Taiwan-Trajectoriesand-Turning-Points-in-Politics/Sullivan-Lee/p/book/9781138062429

Accepted version downloaded from SOAS Research Online: http://eprints.soas.ac.uk/26193/

Nevertheless, the two parties that had the best claim to be social movement parties were the GPT-SDP Alliance and the NPP. In fact there was clear competition between these two over which would be the party that best represented Taiwan's civil society. For both parties, the majority of their nominated candidates had clear social movement backgrounds.

Unsurprisingly the GPT stressed its environmental credentials by nominating its co-convenor Li Gen-zheng (李根政) who also headed environmental NGO Citizens of the Earth on its PR list. Another noteworthy element in the GPT's attempt to reach new voters was to focus on labour related issues. The nomination of Chang Li-fen (張麗芬), the Secretary General of the China Telecom Union, at the top of its party list signified this new approach. One particularly notable GPT appeal has been over gay and lesbian rights, an issue on which the mainstream parties have tended to either ignore or take divided or ambiguous stances on. The GPT was the first party to nominate openly gay candidates in local and national elections. This emphasis was also apparent in the nomination of Hsu Hsiu-wen (許秀文), a leading figure in the Taiwan Partners Rights Promotion Alliance on its party list.

The key themes for the GPT-SDP Alliance in 2016 were visible in its Change TV ad.41 We first see images of before and after at the controversial Miramar Resort, then before and after the Dapu land dispute case, we are reminded of the growing gap between GDP and wages, images of melamine milk to remind voters about food safety scandals, and its ends with the image of a couple kissing at the lesbian wedding ceremony. Thus the party was reminding voters of key issues of concern to social movements. In short, the GPT/SDP attempted to play the role of a genuinely alternative party in its political project. The fact the party failed to reach five percent shows the challenges of such an alternative political project strategy.

Like the GPT, the NPP also markets itself as the representative of the new Taiwanese civil society. Party founder and district candidate Huang Kuo-chang (黃國昌) was one of the three most prominent leaders of the Sunflower movement. An examination of the NPP's party list TV advertisement reveals the movement appeals adopted by the party. The ad showed images of its candidates and supporters at a variety of protests such as the Sunflower occupation, anti nuclear demonstrations, protesting against the Ma-Xi meeting and at gay pride parades. And towards the end of the ad we see a rally scene showing the NPP's Huang with Tsai Ing-wen. Thus a major difference between the GPT/SDP and the NPP was that the latter had a closer working relationship with the DPP. For instance, the parties cooperated in a number of districts, with the DPP leaving three districts for the NPP to stand against the KMT. Overall it appears the NPP's combination of social movement appeals, more famous candidates, cooperation with the DPP, and a clearer national identity position gave it a decisive advantage over its social movement rival the GPT.

\section{Conclusions}

\footnotetext{
${ }^{41}$ https://www.youtube.com/watch?v=C9z6iaXqNao
} 
This chapter has revealed a number of important trends of continuity and change in Taiwan's party scene. While it is true that the challenger parties only made a limited breakthrough and the same two parties remain dominant, 2016 saw major changes in the party system that are likely to have long-term implications. Firstly, it saw the DPP winning a clear national election victory over the KMT and its allies for the first time. It also has left the KMT looking deeply divided, demoralised and led by a leader clearly out of step with mainstream public opinion, its prospects of recovery in the short to medium term look bleak. The arrival of the NPP into parliament is also significant, as it is the first non splinter party to break into the party system and because its hybrid issue appeals are quite distinct from earlier challenger parties. The NPP's performance since entering parliament suggests that it will continue to expand in the next round of local elections in 2018. The election also suggests we are witnessing the demise of the traditional splinter parties, with the failure of the TSU, NP, and MKT. Although the PFP managed to survive in parliament, it is unclear whether it will be able to find a role once Soong eventually retires. The election has again shown that Taiwanese voters tend to punish extremism on both sides of the main issue spectrum. Despite heavy spending, the CUPP, NP and NP all performed disastrously. We have seen how public opinion can shift over a short time period. Only four years earlier the KMT had won a comfortable re-election on its record of promoting cross-strait economic integration, but in 2016 this appeal had become a serious electoral liability. In terms of the issue agenda, the election has shown how Taiwan's politics should not be simply understood as referendums on political relations with China. Instead we have seen how parties need to take broad issue approaches and how a range of social issues became highly salient in this campaign. This means that the new Tsai administration will have significant pressure to address a wide range of domestic reforms or face a similar set of protest movements to those that dogged the Ma government. 